\title{
Progesterone and levonorgestrel regulate expression of 17 beta HSD-enzymes in progesterone receptor positive breast cancer cell line T47D
}

Tove Sivik and Agneta Jansson

\section{Linköping University Post Print}

N.B.: When citing this work, cite the original article.

Original Publication:

Tove Sivik and Agneta Jansson, Progesterone and levonorgestrel regulate expression of 17 beta HSD-enzymes in progesterone receptor positive breast cancer cell line T47D, 2012, Biochemical and Biophysical Research Communications - BBRC, (422), 1, 109-113. http://dx.doi.org/10.1016/j.bbrc.2012.04.116

Copyright: Elsevier http://www.elsevier.com/

Postprint available at: Linköping University Electronic Press http://urn.kb.se/resolve?urn=urn:nbn:se:liu:diva-79104 
$17 \beta H S D$ are enzymes catalysing the conversion between oestrogens

We found that progestins affect the expression of specific 17ßHSD-enzymes

We propose a mechanism for increased breast cancer risk after HRT use with progestins 
Progesterone and Levonorgestrel Regulate Expression of $17 \beta$ HSD-enzymes in Progesterone Receptor Positive Breast Cancer Cell Line T47D

Tove Sivik and Agneta Jansson*

Division of Oncology, Department of Clinical and Experimental Medicine, Faculty of Health Sciences, Linköping University, Department of Oncology, County Council of Östergötland, Linköping, Sweden

Short title: Progestin regulation of $17 \beta H S D-e n z y m e s$

Funding: This work was funded by The Cancer and allergy foundation, Hedlunds foundation, Gösta Miltons foundation, Olle Engkvist Byggmästare foundation, Percy Falk's Foundation and the Cancer Foundation of Östergötland.

${ }^{*}$ Correspondence to: Agneta Jansson, Division of Oncology, Department of Clinical and Experimental Medicine, Cell biology floor 9, Linköping University, Linköping, Sweden e-mail: agneta.jansson@liu.se Phone: +46 101038224; Fax: +46 13127465 


\section{Abstract}

The use of combined hormone replacement therapy (HRT) with oestrogens and progestins in postmenopausal women has been associated with an increased risk for developing breast cancer. The reasons are not fully understood, but influence of HRT on endogenous conversion of female sex hormones may be involved. The expression of 17 beta hydroxysteroid dehydrogenases (17ßHSD), which are enzymes catalysing the conversion between more or less potent oestrogens, may partly be regulated by progestins. The breast cancer cell lines T47D, MCF-7 and ZR75-1 were treated with progesterone, medroxyprogesterone acetate (MPA) or levonorgestrel for 48 and 72 hours at $10^{-7} \mathrm{M}$ and $10^{-9}$ $M$ to investigate influence on $17 \beta$ HSD1, $17 \beta$ HSD2 and $17 \beta$ HSD5 mRNA expression measured by real time PCR. The expression of $17 \beta H S D 1$ increased in progesterone and levonorgestrel treated T47D cells $\left(48 \mathrm{~h} 10^{-7} \mathrm{M} \mathrm{P}=0.002 ; \mathrm{P}<0.001\right)$ and 17ßHSD5 increased after progesterone treatment $\left(48 \mathrm{~h} 10^{-7} \mathrm{M} \mathrm{P}=0.003\right)$, whereas the expression of $17 \beta \mathrm{HSD} 2$ decreased after the $\left(48 \mathrm{~h} 10^{-7} \mathrm{M} \mathrm{P}=0.003 ; \mathrm{P}<0.001\right)$. Similar, but less prominent effects were seen in MCF7 and ZR75-1. The progestin effects on 17ßHSD-expression were lost when T47D-cells were co-treated with progestins and the progesterone receptor $(\mathrm{PgR})$ inhibitor mifprestone. We show that both reductive (17ßHSD1 and 17ßHSD5) and oxidative $(17 \beta H S D 2)$ members of the $17 \beta H S D$-family are under control of progesterone and progestins in breast cancer cell lines. This is most clear in T47D cells which have high PgR expression. $17 \beta H S D$ enzymes are important players in the regulation of sex steroids locally in breast tumours and tumoural expression of various 17ßHSD-enzymes have prognostic and treatment predictive relevance. We propose a mechanism for increased breast cancer risk after HRT in which hormone replacement affects the expression of $17 \beta H S D$-enzymes, favouring the expression of reductive enzymes, which in turn could increase levels of bioactive and mitogenic estrogens in local tissue, e.g. breast tissue.

Keywords: Breast cancer, Progestin, progesterone, 17ßHSD1, 17ßHSD2 


\section{Introduction}

Hormone replacement therapy (HRT), which typically contains oestrogens or oestrogens in combination with progestin, is given to women to ease discomfort associated with reduced circulating female sex hormones at menopause. The use of HRT was greatly reduced after a report from the Women's Health Initiative which showed an increased risk of breast cancer for women receiving progestins in combination with oestradiol compared to oestradiol treatment alone [1]. This association has since been confirmed in several other studies. The breast cancer risk associated with HRT is higher for oestrogen receptor (ER)-positive cancers than for ER-negative cancers [2-5].

One in ten women will be affected by breast cancer during their life time. Several risk factors have been proposed, among them exposure to female sex hormones. The importance of oestrogens is illustrated by the fact that approximately $80 \%$ of all breast cancers express high levels of ER. Although progesterone is vital for normal growth and development of the breast, the role of this female sex hormone in the development of breast cancer, either as a single actor or as a regulator of oestrogen signalling, is under debate $[6,7]$. The progesterone receptor $(\mathrm{PgR})$ is an oestrogen responsive gene, and the presence of $\mathrm{PgR}$ is often used as a marker for functional ER signalling. Progestins are designed to mimic progesterone but with a longer half-life and better availability, however, their mechanism of action is not fully understood. It is clear that different progestins exert different effects that may be due to metabolism, dose variation, pharmacokinetics and effects mediated by steroidogenic enzymes [8]. Even though the main targets of progestins are steroid receptors, they may also bind mineralocortico receptors (MR), androgen receptors (AR) or glucocorticoid receptors (GR) [9].

$17 \beta$ hydroxysteroid dehydrogenases (17ßHSD), is a family of enzymes involved regulating the availability of more or less biologically potent sex hormones. 17ßHSD1 efficiently catalyses the reduction of oestrone to oestradiol, whereas $17 \beta H S D 2$ catalyses the oxidation 
of oestradiol to oestrone, testosterone to androstendione and dihydrotestosterone to $5 \alpha$ androstendione. 17ßHSD5 converts androstendione to testosterone and oestrone to oestradiol. We have previously shown that $17 \beta$ HSD1, 17ßHSD2, $17 \beta$ HSD 5 and $17 \beta H S D 14$ are important as prognostic and treatment predictive factors in breast cancer [10-13]. It has been shown that progestins influence the oestradiol and testosterone levels, and these effects have been presumed to be an effect caused by altered regulation of $17 \beta \mathrm{HSD}$ enzymes; however the contribution of separate family members of the $17 \beta H S D$-family has not been addressed [14-19].

Our aim was to investigate potential roles/contributions of individual $17 \beta H S D$-enzymes for the altered sex hormone conversion seen after treatment with progesterone/progestins in vitro as well as in vivo. We investigated the effect of progesterone or progestins (levonorgestrel and medroxyprogesterone acetate (MPA)) on the expression levels of 17ßHSD1, 17ßHSD2 and 17ßHSD5 in breast cancer cell lines T47D, MCF7 and ZR75-1 measured with semi-quantitative realtime-PCR. Furthermore, in order to study whether detected changes were mediated by $\mathrm{PgR}$, cells were treated with progesterone and progestins in combination with the $\mathrm{PgR}$ inhibitor mifepristone. 


\section{Material and methods}

\section{Cell culture and treatment}

T47D, MCF7 and ZR75-1 breast cancer epithelial cells (American Type Culture Collection, Manassas, VA) were cultured in phenol-red free Opti- Mem I (Invitrogen, Carlsbad, CA) supplemented with $4 \%$ foetal bovine serum (FBS; Invitrogen, Carlsbad, CA) and incubated at $37^{\circ} \mathrm{C}, 5 \% \mathrm{CO}_{2}$. In all experiments charcoal/dextran treated serum (CTS; HyClone, Utah, USA) was used to control the levels of hormones. The experiments with T47D were performed between passage 100 and 104, MCF7 between passage 151 and 157 and ZR751 between passage 91 and 93 . The cells were seeded in twelve-well plates in $1 \mathrm{~mL} /$ well in culture medium 30 000/well for T47D cells , 60 000/well MCF7 and 30 000/well for ZR751. Twenty-four hours after seeding, the cells were treated with either progesterone $10^{-7} \mathrm{M}$ or $\mathrm{P}$ $10^{-9} \mathrm{M}$, MPA $10^{-7} \mathrm{M}$ or $10^{-9} \mathrm{M}$ and levonorgestrel $10^{-7} \mathrm{M}$ or $10^{-9} \mathrm{M}$ (Sigma-Aldrich, St Louis, MO) for 48 and 72 hours, a vehicle control was treated in the same way. The cells received new hormone medium every 24 hour. All experiments were performed in triplicate and repeated three times.

\section{Inhibition with Mifprestone}

To identify changes mediated via PgR, T47 D cells were treated with mifprestone $10^{-7} \mathrm{M}$ (Sigma-Aldrich); mifprestone $10^{-7} \mathrm{M}$ and progesterone $10^{-7}$ or $10^{9} \mathrm{M}$, mifpresone $10^{-7} \mathrm{M}$ and levonorgestrel $10^{-7}$ or $10^{-9} \mathrm{M}$; and mifprestone $10^{-7} \mathrm{M}$ and MPA $10^{-7}$ and $10^{-9} \mathrm{M}$ for 48 hours, a vehicle control was included. The cells received new hormone medium every 24 hour. The experiment was performed in triplicate and repeated three times.

\section{Western blot}

To compare protein expression of PgR and ER, cultured MCF7, T47D and ZR75-1 cells were lysed. The same amount of protein/lane was loaded onto $4-15 \%$ gradient precast gels (Criterion, Bio-Rad, Hercules, CA). The proteins were transferred to PVDF membranes that were further incubated overnight with ER antibody (Mus ERa/NR3A1 (Clone H4624), 1 mg/ml, R\&D systems, Minneapolis, MN, USA) or PgR antibody (Rabbit anti Pgr 1:1000, Cell 
signalling, Beverly, MA, USA). To control for equal loading the membrane was incubated with B-actin antibody (1:2000, Cell signalling). Binding of the antibodies to the membranes was detected using a commercial ECL-Plus kit (GE Health care UK limited, Little Chalfont, UK). Results were visualised using LAS1000 CCD-camera detection system (FujiFilm, Tokyo, Japan).

\section{Semi-quanitative Real time-PCR}

RNA was extracted 48 and 72 hours after treatment using SV Total RNA Isolation System (Promega, Madison, WI). The RNA was stored at $-70^{\circ} \mathrm{C}$. Synthesis of cDNA from total RNA was performed using the $1^{\text {st }}$ strand cDNA Synthesis kit with random hexameres (Roche Diagnostics Corporation, Indianapolis, IN, USA). mRNA expression of 17ßHSD1 and $17 \beta H S D 2$ was analysed according to Gunnarsson et al. [11] and 17ßHSD5 according to Jansson et al [13]. $\beta$-actin was used as endogenous reference gene and the assay was purchased from Applied Biosystems (Warrington, UK). Standard curves for all analysed genes were run on each plate, using serially diluted cDNA to normalise the runs. The obtained data from $\beta$-actin was used to normalise the sample variation in the amount of input cDNA. All samples were run as triplicates and in all experiments samples without template were used as control. The relative quantification of $17 \beta H S D 1,17 \beta H S D 2$, and $17 \beta H S D 5$ were performed according to the manufacturer's description (Protocol P/N 4303859, Pearkin Elmer).

\section{Statistical evaluation}

Students t-test was used for comparison between treated samples and the control. The results are expressed as \pm SE of the mean values, obtained from three replicates repeated three times. All P-values are two sided, and $p<0.05$ was considered to be statistically significant. All the procedures were comprised in the statistical package STATISTICA 8.0 (StatSoft Scandinavia AB, Sweden). 


\section{Results}

17ßHSD1, 17ßHSD2 and 17ßHSD5 expression in T47D, MCF7 and ZR75-1

The relative expression of $17 \beta H S D 1,17 \beta H S D 2$ and $17 \beta H S D 5$ were analysed in untreated breast cancer cell lines, T47D, MCF7 and ZR75-1. T47D cells expressed high levels of $17 \mathrm{HSD} \beta 1$; intermediate levels of $17 \beta \mathrm{HSD} 2$, and intermediate e $17 \beta \mathrm{HSD} 5$ levels; MCF7 expressed low levels of 17ßHSD1, low levels of $17 \beta \mathrm{HSD} 2$ and intermediate levels of $17 \beta H S D 5$; and ZR75-1 expressed intermediate levels of $17 \mathrm{HSD} \beta 1$, low levels of $17 \mathrm{HSD} \beta 2$ and intermediate levels of $17 \beta$ HSD5 (Table 1).

\section{PgR and ER expression in T47D, MCF7 and ZR75-1}

The highest protein expression level of $\mathrm{PgR}$ was detected in T47D, intermediate/low expression in ZR75-1 and MCF-7, in line with previous measurements. Further, ER expression was high in T47D and MCF-7, and intermediate in ZR75-1.

\section{$17 \beta H S D 1,17 \beta H S D 2$ and $17 \beta H S D 5$ expression after progesterone, levonorgestrel and MPA treatment in T47D cells}

Progesterone induced expression of $17 \beta \mathrm{HSD} 1$ in T47D cells $\left(48 \mathrm{~h} 10^{-7} \mathrm{M} P=0.002,10^{-9} \mathrm{M}\right.$

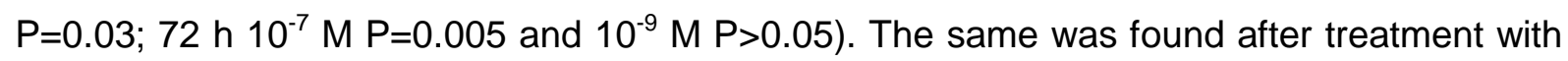
levonorgestrel $\left(48\right.$ h $10^{-7} \mathrm{M} \mathrm{P}=0.0007,10^{-9} \mathrm{M} \mathrm{P}=0.0004 ; 72 \mathrm{~h} 10^{-7} \mathrm{M} \mathrm{P}=0.0006$ and $10^{-9} \mathrm{M}$ $\mathrm{P}=0.01$ ) (Fig 1a). No changes were detected after MPA treatment. Further, the expression of $17 \beta \mathrm{HSD} 2$ was reduced when treated with progesterone $\left(48 \mathrm{~h} 10^{-7} \mathrm{M} \mathrm{P}=0.003,10^{-9} \mathrm{M}\right.$

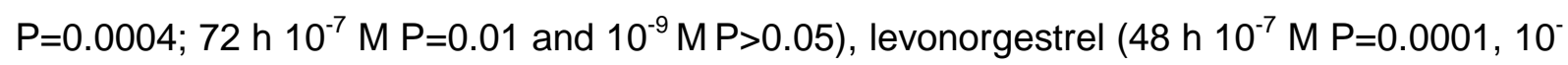
${ }^{9} \mathrm{M} \mathrm{P}=0.005 ; 72 \mathrm{~h} 10^{-7} \mathrm{M} \mathrm{P}>0.05$ and $\left.10^{-9} \mathrm{MP}=0.04\right)$ and MPA (48 h $10^{-7} \mathrm{M} \mathrm{P}=0.009,10^{-9} \mathrm{M}$

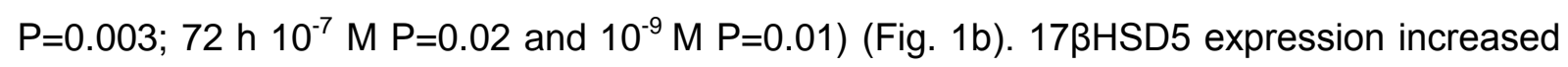
after 48 hours of progesterone $\left(10^{-7} \mathrm{M} \mathrm{P}=0.003,10^{-9} \mathrm{M} P>0.05\right)$ and MPA treatment (48 $\mathrm{h} 10^{-}$ ${ }^{7} \mathrm{M} P>0.05,10^{-9} \mathrm{M} \mathrm{P}=0.001$ ). After 72 hours, expression levels of $17 \beta \mathrm{HSD} 5$ decreased in cells treated with progesterone $\left(10^{-7} \mathrm{M} \mathrm{P}=0.0110^{-9} \mathrm{M} P>0.05\right)$, levonorgestrel $\left(10^{-7} \mathrm{M}\right.$ $\left.\mathrm{P}=0.02,10^{-9} \mathrm{M} \mathrm{P}=0.03\right)$ and MPA treatment (48 h $\left.10^{-7} \mathrm{M} \mathrm{P}=0.01,10^{-9} \mathrm{M} \mathrm{P}=0.03\right)$ (Fig.1c).

$17 \beta H S D 1,17 \beta H S D 2$, and $17 \beta H S D 5$ expression after progesterone, levonorgestrel and MPA treatment in MCF7 cells 
In MCF7 cells $17 \beta$ HSD1 expression levels increased after progesterone (48 h $10^{-7} \mathrm{M}$ $\mathrm{P}=0,001,10^{-9} \mathrm{MP}=0.0004 ; 72 \mathrm{~h} 10^{-7} \mathrm{M} \mathrm{P}>0.05$ and $10^{-9} \mathrm{M} P>0.05$ ) (Fig. 2a) and MPA

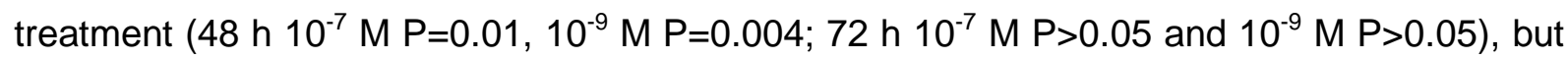
not after treatment with levonorgestrel $(P>0.05)$. Expression levels of $17 \beta H S D 2$ were not affected. 17ßHSD5 expression increased after progesterone (48 h $10^{-7} \mathrm{M} P>0.05,10^{-9} \mathrm{M}$ $\mathrm{P}>0.05 ; 72 \mathrm{~h} 10^{-7} \mathrm{M} \mathrm{P}=0.02$ and $\left.10^{-9} \mathrm{M} P>0.05\right)$ and MPA treatment (48 h $10^{-7} \mathrm{M} P>0.05,10^{-}$ ${ }^{9} \mathrm{M} P>0.05 ; 72 \mathrm{~h} 10^{-7} \mathrm{M} \mathrm{P}=0.02$ and $10^{-9} \mathrm{M} \mathrm{P}=0.004$ ) (Fig. 2b), but not after levonorgestrel exposure.

\section{$17 \beta H S D 1,17 \beta H S D 2$ and $17 \beta H S D 5$ expression after progesterone, levonorgestrel and} MPA treatment in ZR751 cells

No changes in expression levels of neither $17 \beta H S D 1$ nor $17 \beta H S D 2$ at any time point was detected in ZR75-1 cells when treated with progesterone, levonorgestrel or MPA $(P>0.05)$. However, $17 \beta \mathrm{HSD} 5$ expression increased after progesterone $\left(48 \mathrm{~h} 10^{-7} \mathrm{M} P>0.05,10^{-9} \mathrm{M}\right.$

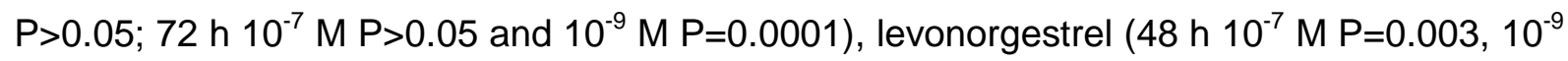

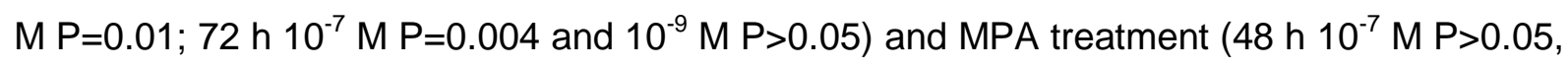

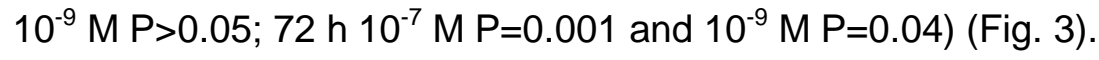

\section{Mifepristone inhibits the induction of 17ßHSD1 and 17ßHSD5 in T47D}

To investigate if the changed expression levels detected were mediated by the progesterone receptor, T47D cells were treated with mifprestone, vehicle, progesterone and mifprestone, levonorgestrel and mifprestone or MPA and mifprestone for $48 \mathrm{~h}$. No changes in expression levels of $17 \beta$ HSD1, $17 \beta$ HSD2 or $17 \beta$ HSD5 were detected when the different treatments were compared $(\mathrm{P}>0.05)$. 


\section{Discussion}

Women receiving HRT run an increased risk of developing breast cancer when progestins are combined with oestradiol [1-5]. 17ßHSD-enzymes have been found to play important roles in the development of breast cancer, possibly through their impact on the fine tuning of sex steroid levels. Progestins have been shown to induce conversion of oestrone to oestrasiol and vice versa in breast cancer cell lines, and this alteration in sex steroid conversion has been assumed to be a regulatory effect of $17 \beta H S D$-enzymes caused by progestins [14-19].

To study the effect of progesterone and progestins on the expression of $17 \beta \mathrm{HSD}$-enzymes, we used progesterone and the most commonly used progestin in Europe and the US which are levenorgestrel and MPA respectively. The pysiological concentration detected in serum ranges from 0.1-10 nM in women using $\mathrm{HRT}[8,20,21]$. We treated the cells with two different concentrations of progesterone/progestins reflecting the serum levels detected after HRT use. We could show that progesterone and progestins in deed does affect the levels of individual $17 \beta H S D$-enzymes in breast cancer cell lines, but that the degree to which individual $17 \beta H S D$-enzymes were affected and by which progesterone/progestin, varied to some extent. The expression level of $\mathrm{PgR}$ and $\mathrm{ER}$ varied in the cell lines, with the highest expression of $\mathrm{PgR}$ in T47D, intermediate in MCF7 and low in ZR75-1, this is in agreement with previous findings. [22]. The effect was most apparent in T47D which has a high PgR expression. In this cell line, treatment with levonorgestrel and progesterone led to the upregulation of reductive $17 \beta H S D$-enzymes $17 \beta H S D 1$ and $17 \beta H S D 5$ whereas the oxidative $17 \beta H S D 2$ was down-regulated. MPA did not affect 17ßHSD1-expression in this cell line, although $17 \beta$ HSD5 was upregulated. The absence of effects when co-treating T47D-cells with progestins and the PgR-inhibitor mifprestone indicates that the regulation of $17 \beta \mathrm{HSD}$ enzymes in this cell line is mediated via activation of PgR. This is in agreement with previous results showing that mifprestone blocks progestin induced steroid conversion in T47D cells [18]. Alterations were also seen in MCF7 and ZR75-1 with lower PgR expression. Adams et 
al [14] showed progestin induced changes in both reductive (oestrone to oestradiol) and oxidative (oestradiol to oestrone) activity in MCF-7. An increase in oestrone to oestradiol conversion could, at least partly, be explained by increases in 17ßHSD1 and 17ßHSD5 gene expression seen after progesterone and MPA treatment of MCF7, although, no changes were seen in $17 \beta \mathrm{HSD} 2$-expression which could explain the altered oestradiol to oestrone conversion. Couture et al [16] reported MPA induced changes in both oxidative and reductive activity in ZR75-1 cells, and furthermore, that the MPA-induced changes were inhibited by an anti-androgen, suggesting involvement of male sex hormones. In our hands, levonogestrel, but not MPA, increased the expression of $17 \beta H S D 5$, which converts androstenedione into more potent testosterone, in ZR75-1, whereas MPA failed to induce this change. Although $\mathrm{PgR}$ seems to be important for the effects mediated by progestins, at least in a cell line harbouring high expression levels of the receptor such as T47D, there is a possibility that other steroid receptors could be involved when $\mathrm{PgR}$ is low or absent, and this may in part explain why the different cell lines respond differently to progesterone and different progestins. In addition to $\mathrm{PgR}$, progestins have been reported to bind to $\mathrm{GR}, \mathrm{AR}$ and $\mathrm{MR}$, and also ER, and the extent to which these receptors are activated by different progestins may be dose dependent [23-27]. The failure of MPA to induce 17ßHSD1-expression in T47D could be an indication that this progestin operates on other steroid receptors, e.g. the AR. There are studies indicating that MPA in fact inhibits the proliferation in MCF-7, ZR75-1 and T47D cells through GR and AR [28-30].

We have investigated enzymes which have so far been attributed most relevance in breast cancer; however other 17ßHSD-enzymes may also be of importance. A reason for inconsistencies between our data and previously published data on the effects of progestin stimulation on $17 \beta \mathrm{HSD}$-activity could be generated by the relative redundancy within the $17 \beta$ HSD-family, where it is unknown to what extent individual enzymes are actually involved in affecting the levels of bioactive sex steroids. Data concerning $17 \beta H S D 14$, which was 
assessed but not presented, revealed no changes in any cell line analysed which indicates this enzyme to be of minor importance in the current setting.

Our data suggest that systemic treatment with progesterone and progestins could alter the expression levels of individual $17 \beta \mathrm{HSD}$-enzymes, in general favouring the expression of reductive enzymes over oxidative enzymes in local tissue, e.g. breast tissue. Unopposed, this change in enzyme expression would lead to an increase in bioactive female sex steroids, e.g. oestradiol, which through its mitogenic interaction with the ER could enhance proliferation of breast epithelial cells. Schonnen et al [31] showed that levenorgestrel stimulated proliferation in MCF-7 cells through ER. It had been suggested that metabolites to progestins may bind directly to ER. In our experiments levernogestrel increased expression of $17 \beta \mathrm{HSD} 1$, decreased $17 \beta \mathrm{HSD} 2$ and increased $17 \beta \mathrm{HSD} 5$ expression, showing that progestins can indirectly influence ER activity through the regulation of steroid converting enzymes which in turn would lead to altered activity of ER.

In summary, we show that both reductive (17ßHSD1 and 17ßHSD5) and oxidative (17ßHSD2) members of the $17 \beta H S D$-family are under control of progesterone and progestins in breast cancer cell lines. This is most clear in T47D cells which have high PgR expression. $17 \beta H S D$ enzymes are important players in the regulation of sex steroids locally in breast tumours and tumoural expression levels of various $17 \beta \mathrm{HSD}$-enzymes have been found to be of prognostic and treatment predictive relevance. We propose a mechanism for increased breast cancer risk after HRT in which hormone replacement affects the expression of $17 \beta H S D$-enzymes, favouring the expression of reductive enzymes, which in turn could increase levels of bioactive and mitogenic estrogens in local tissue, e.g. breast tissue. Given this background, inhibition of $\mathrm{PgR}$ may be beneficial for breast cancer patients. 


\section{References}

1. Rossouw JE, Anderson GL, Prentice RL, LaCroix AZ, Kooperberg C, et al. (2002) Risks and benefits of estrogen plus progestin in healthy postmenopausal women: principal results From the Women's Health Initiative randomized controlled trial. JAMA 288: 321-333.

2. Beral V, Reeves G, Bull D, Green J, Million Women Study C (2011) Breast cancer risk in relation to the interval between menopause and starting hormone therapy. J Natl Cancer Inst 103: 296305.

3. Chlebowski RT, Anderson GL, Gass M, Lane DS, Aragaki AK, et al. (2010) Estrogen plus progestin and breast cancer incidence and mortality in postmenopausal women. JAMA 304: 16841692.

4. Narod SA (2011) Hormone replacement therapy and the risk of breast cancer. Nat Rev Clin Oncol 8: 669-676.

5. Chlebowski RT, Hendrix SL, Langer RD, Stefanick ML, Gass M, et al. (2003) Influence of estrogen plus progestin on breast cancer and mammography in healthy postmenopausal women: the Women's Health Initiative Randomized Trial. JAMA 289: 3243-3253.

6. Lee HJ, Ormandy CJ (2011) Interplay between progesterone and prolactin in mammary development and implications for breast cancer. Mol Cell Endocrinol.

7. Stingl J (2011) Estrogen and progesterone in normal mammary gland development and in cancer. Horm Cancer 2: 85-90.

8. Africander D, Verhoog N, Hapgood JP (2011) Molecular mechanisms of steroid receptor-mediated actions by synthetic progestins used in HRT and contraception. Steroids 76: 636-652.

9. Moore NL, Hickey TE, Butler LM, Tilley WD (2011) Multiple nuclear receptor signaling pathways mediate the actions of synthetic progestins in target cells. Mol Cell Endocrinol.

10. Gunnarsson C, Hellqvist E, Stal O (2005) 17beta-Hydroxysteroid dehydrogenases involved in local oestrogen synthesis have prognostic significance in breast cancer. Br J Cancer 92: 547-552.

11. Gunnarsson C, Olsson BM, Stal O, Southeast Sweden Breast Cancer G (2001) Abnormal expression of 17 beta-hydroxysteroid dehydrogenases in breast cancer predicts late recurrence. Cancer Res 61: 8448-8451.

12. Jansson A, Delander L, Gunnarsson C, Fornander T, Skoog L, et al. (2009) Ratio of 17HSD1 to 17 HSD2 protein expression predicts the outcome of tamoxifen treatment in postmenopausal breast cancer patients. Clin Cancer Res 15: 3610-3616.

13. Jansson AK, Gunnarsson C, Cohen M, Sivik T, Stal O (2006) 17beta-hydroxysteroid dehydrogenase 14 affects estradiol levels in breast cancer cells and is a prognostic marker in estrogen receptor-positive breast cancer. Cancer Res 66: 11471-11477.

14. Adams EF, Coldham NG, James VH (1988) Steroidal regulation of oestradiol-17 beta dehydrogenase activity of the human breast cancer cell line MCF-7. J Endocrinol 118: 149154.

15. Coldham NG, James VH (1990) A possible mechanism for increased breast cell proliferation by progestins through increased reductive 17 beta-hydroxysteroid dehydrogenase activity. Int J Cancer 45: 174-178.

16. Couture P, Theriault C, Simard J, Labrie F (1993) Androgen receptor-mediated stimulation of 17 beta-hydroxysteroid dehydrogenase activity by dihydrotestosterone and medroxyprogesterone acetate in ZR-75-1 human breast cancer cells. Endocrinology 132: 179185.

17. Malet C, Vacca A, Kuttenn F, Mauvais-Jarvis P (1991) 17 beta-estradiol dehydrogenase (E2DH) activity in T47D cells. J Steroid Biochem Mol Biol 39: 769-775.

18. Poutanen M, Isomaa V, Kainulainen K, Vihko R (1990) Progestin induction of 17 betahydroxysteroid dehydrogenase enzyme protein in the T-47D human breast-cancer cell line. Int J Cancer 46: 897-901. 
19. Shields-Botella J, Chetrite G, Meschi S, Pasqualini JR (2005) Effect of nomegestrol acetate on estrogen biosynthesis and transformation in MCF-7 and T47-D breast cancer cells. J Steroid Biochem Mol Biol 93: 1-13.

20. Fotherby K (1983) Variability of pharmacokinetic parameters for contraceptive steroids. J Steroid Biochem 19: 817-820.

21. Shrimanker K, Saxena BN, Fotherby K (1978) A radioimmunoassay for serum medroxyprogesterone acetate. J Steroid Biochem 9: 359-363.

22. Hung H (2004) Inhibition of estrogen receptor alpha expression and function in MCF-7 cells by kaempferol. J Cell Physiol 198: 197-208.

23. Krattenmacher R (2000) Drospirenone: pharmacology and pharmacokinetics of a unique progestogen. Contraception 62: 29-38.

24. Kuhl H (2005) Pharmacology of estrogens and progestogens: influence of different routes of administration. Climacteric 8 Suppl 1: 3-63.

25. Mueck AO, Sitruk-Ware R (2011) Nomegestrol acetate, a novel progestogen for oral contraception. Steroids 76: 531-539.

26. Schindler AE, Campagnoli C, Druckmann R, Huber J, Pasqualini JR, et al. (2003) Classification and pharmacology of progestins. Maturitas 46 Suppl 1: S7-S16.

27. Winneker RC, Bitran D, Zhang Z (2003) The preclinical biology of a new potent and selective progestin: trimegestone. Steroids 68: 915-920.

28. Bentel JM, Birrell SN, Pickering MA, Holds DJ, Horsfall DJ, et al. (1999) Androgen receptor agonist activity of the synthetic progestin, medroxyprogesterone acetate, in human breast cancer cells. Mol Cell Endocrinol 154: 11-20.

29. Poulin R, Baker D, Poirier D, Labrie F (1991) Multiple actions of synthetic 'progestins' on the growth of ZR-75-1 human breast cancer cells: an in vitro model for the simultaneous assay of androgen, progestin, estrogen, and glucocorticoid agonistic and antagonistic activities of steroids. Breast Cancer Res Treat 17: 197-210.

30. Vilasco M, Communal L, Mourra N, Courtin A, Forgez P, et al. (2011) Glucocorticoid receptor and breast cancer. Breast Cancer Res Treat 130: 1-10.

31. Schoonen WG, Joosten JW, Kloosterboer HJ (1995) Effects of two classes of progestagens, pregnane and 19-nortestosterone derivatives, on cell growth of human breast tumor cells: II. T47D cell lines. J Steroid Biochem Mol Biol 55: 439-444. 


\section{Figure legends}

\section{Figure 1. Progestin treatment of T47D cells}

T47 D cells treated with progesterone $(P)$, levenorgestrel $(L)$ or medroxyprogesterone acetate (MPA) for 48 or 72 hours in relation to untreated control, concerning A) $17 \beta H S D 1$; B) $17 \beta H S D 2$ and C) $17 \beta H S D 5$. The results represent mean of a representative experiment $\pm \mathrm{SE},{ }^{*}<0.05,{ }^{* *}<0.01,{ }^{* * *}<0.001$

\section{Figure 2. Progestin treatment of MCF7 cells}

MCF7 cells treated with progesterone $(P)$, levenorgestrel $(L)$ or medroxyprogesterone acetate (MPA) for 48 or 72 hours in relation to untreated control, concerning A) 17ßHSD1 and B) $17 \beta H S D 5$. The results represent mean of a representative experiment $\pm S E,{ }^{*}<0.05$, ${ }^{* *}<0.01,{ }^{* * *}<0.001$

\section{Figure 3. Progestin treatment of ZR75-1 cells}

ZR75-1 cells treated with progesterone $(P)$, levenorgestrel $(L)$ or medroxyprogesterone acetate (MPA) for 48 or 72 hours in relation to untreated control, concerning A) 17ßHSD5. The results represent mean of a representative experiment $\pm \mathrm{SE},{ }^{*}<0.05,{ }^{* *}<0.01,{ }^{* * *}<$ 0.001 

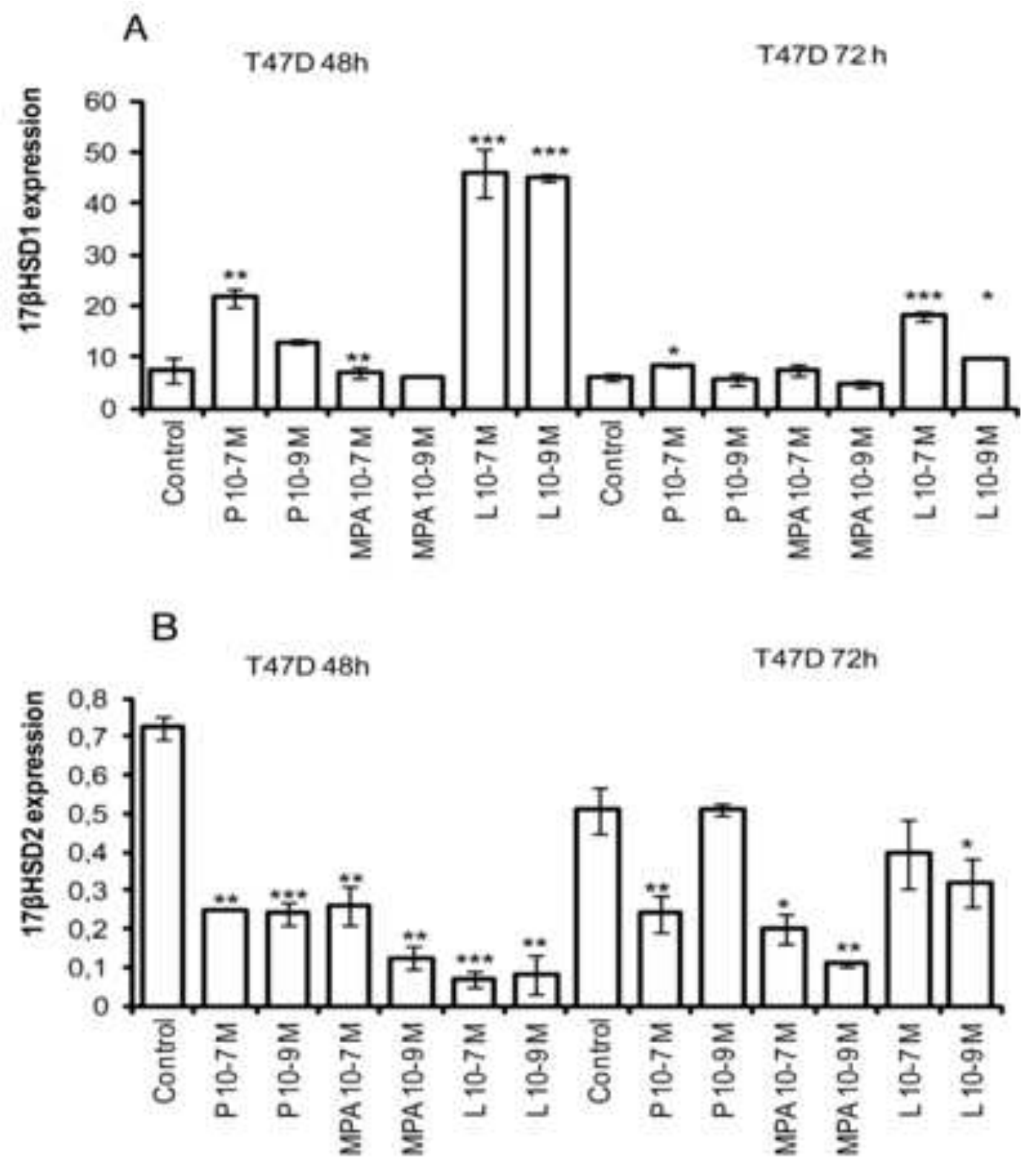

C

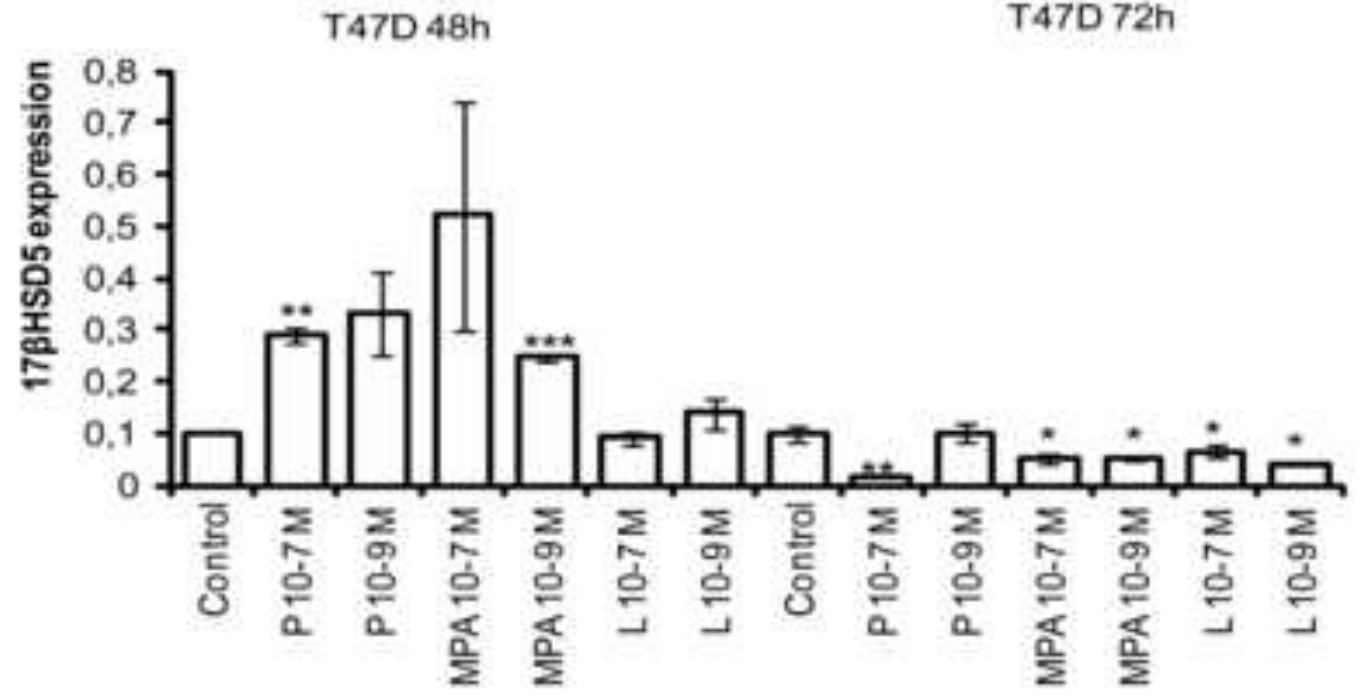


A

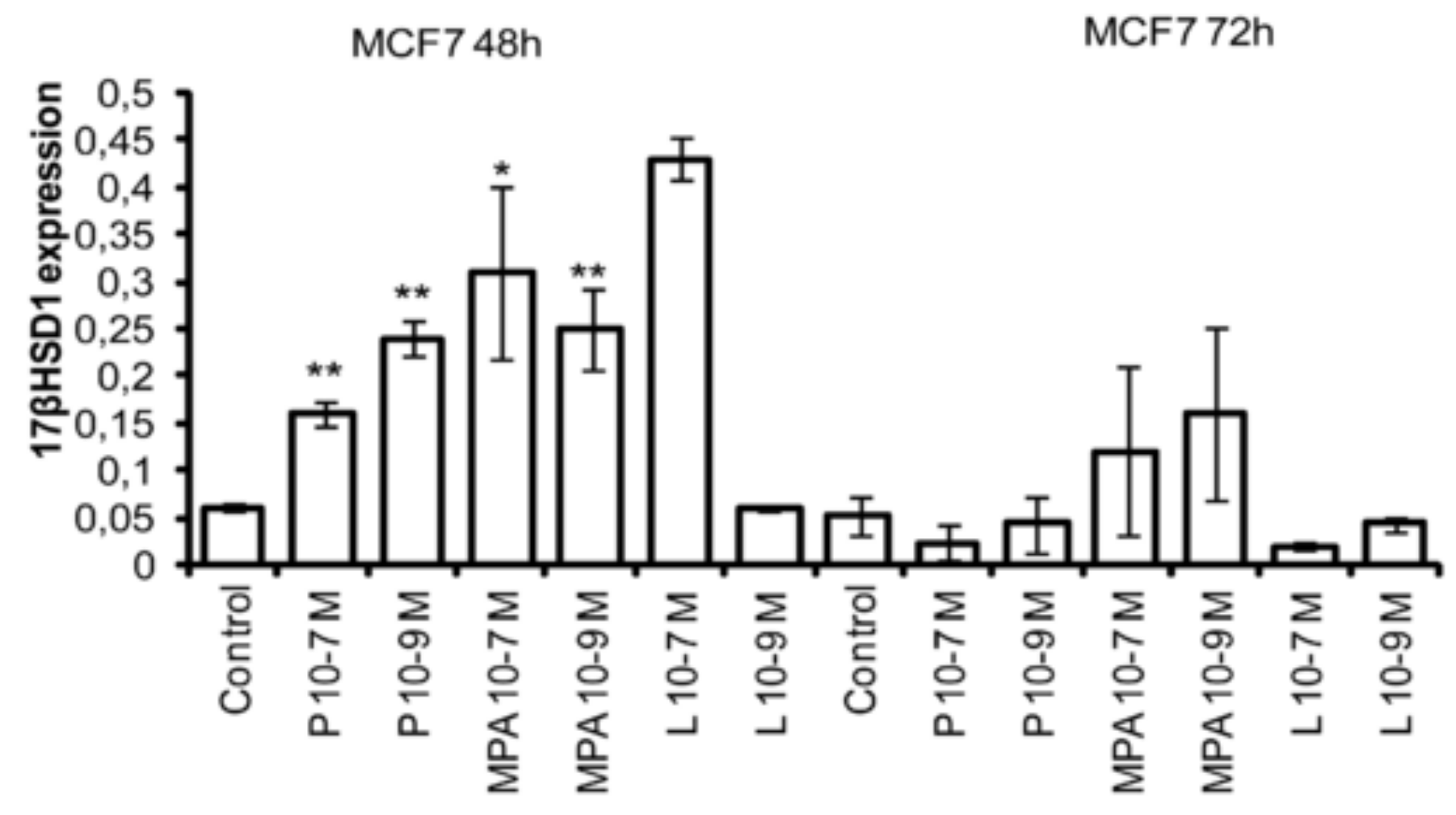

B

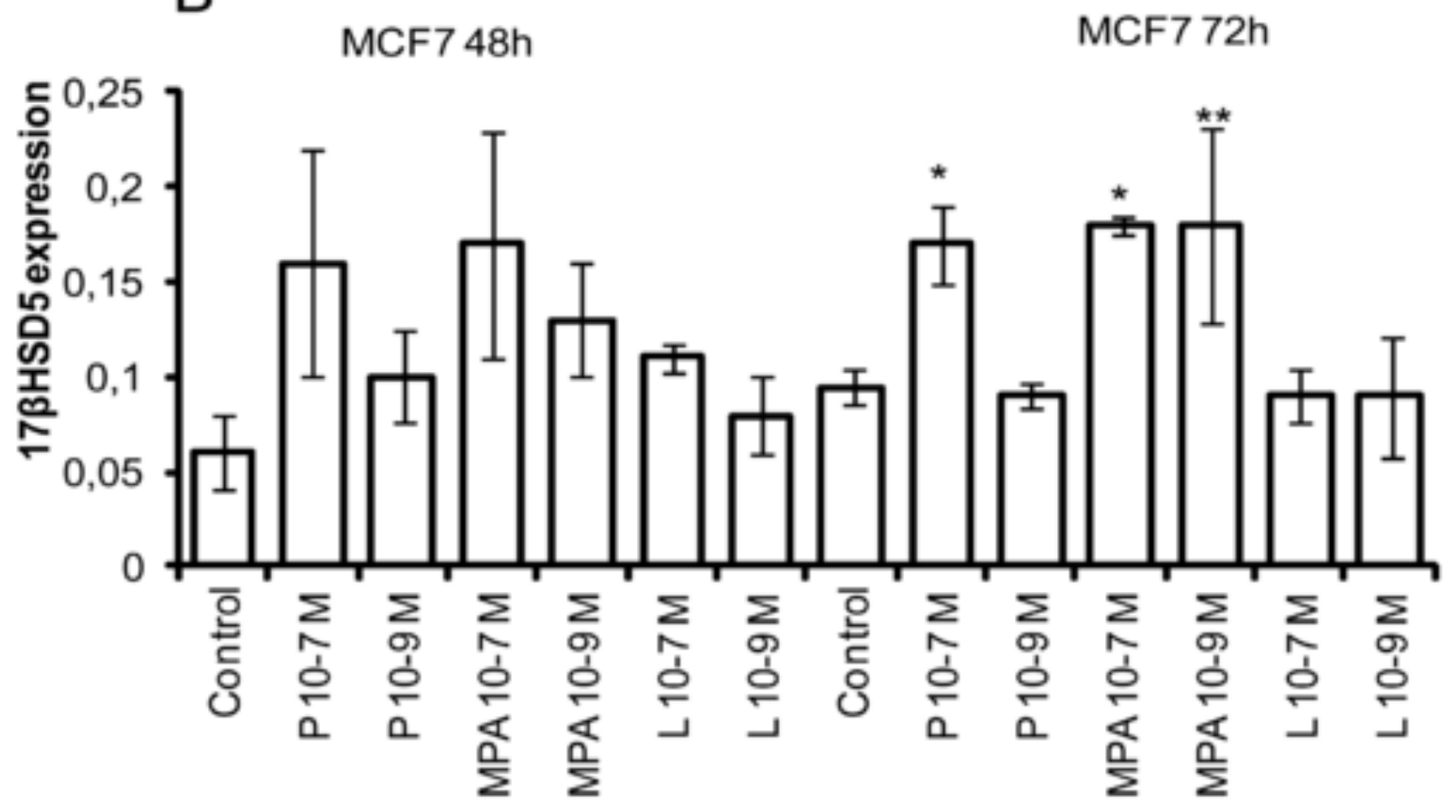


ZR75-148h

ZR75-172h

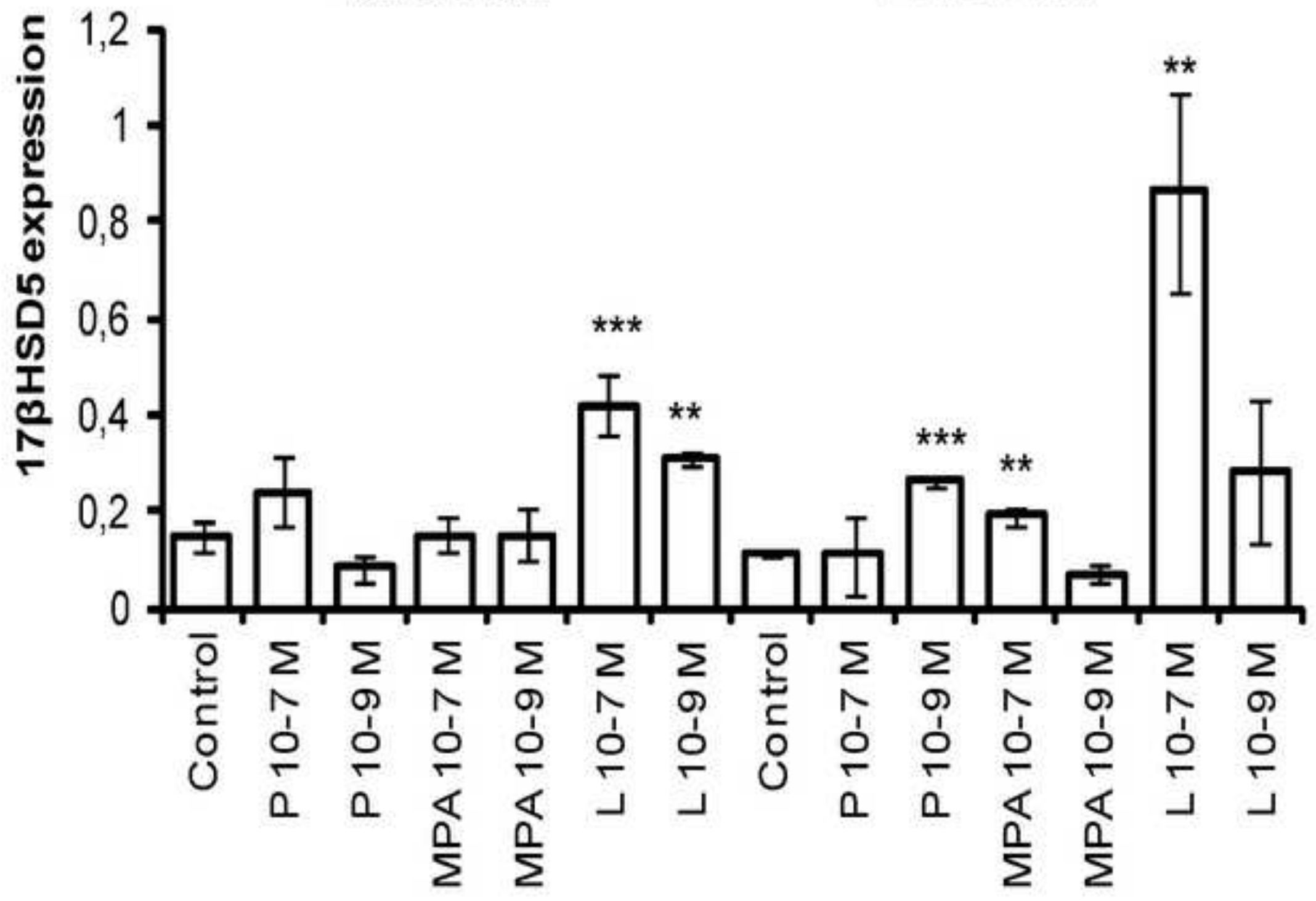


Table

Table 1. Endogenous expression levels of 17ßHSD1, 17ßHSD2 and 17ßHSD5 in untreated breast cancer cells, presented as mean of a representative experiment \pm SE.

$\begin{array}{llll} & 17 \beta H S D 1 & 17 \beta H S D 2 & 17 \beta H S D 5 \\ \text { T47D } & 7.42 \pm 0.35 & 0.52 \pm 0.06 & 0.10 \pm 0.01 \\ \text { MCF7 } & 0.05 \pm 0.02 & 0.003 \pm 0.002 & 0.095 \pm 0.01 \\ \text { ZR75-1 } & 0.81 \pm 0.19 & 0.11 \pm 0.07 & 0.11 \pm 0.006\end{array}$

